Marquette University Law School

Marquette Law Scholarly Commons

Faculty Publications

Faculty Scholarship

$1-1-1998$

\title{
A Review of Federal Sentencing Treatises and Periodicals
}

Michael M. O'Hear

Marquette UniversityLaw School, michael.ohear@marquette.edu

Follow this and additional works at: http://scholarship.law.marquette.edu/facpub

Part of the Law Commons

Publication Information

Michael M. O'Hear, A Review of Federal Sentencing Treatises and Periodicals, 11 Fed. Sent'g Rep. 69 (1998). (C) 1998 by the Regents of the University of California on behalf of the Vera Institute of Justice. Copying and permissions notice: Authorization to copy this content beyond fair use (as specified in Sections 107 and 108 of the U. S. Copyright Law) for internal or personal use, or the internal or personal use of specific clients, is granted by the Regents of the University of California on behalf of the Vera Institute of Justice for libraries and other users, provided that they are registered with and pay the specified fee via Rightslink ${ }^{\circledast}$ on Caliber (http://caliber.ucpress.net/) or directly with the Copyright Clearance Center, http://www.copyright.com.

\section{Repository Citation}

O'Hear, Michael M., "A Review of Federal Sentencing Treatises and Periodicals" (1998). Faculty Publications. Paper 494.

http://scholarship.law.marquette.edu/facpub/494

This Article is brought to you for free and open access by the Faculty Scholarship at Marquette Law Scholarly Commons. It has been accepted for inclusion in Faculty Publications by an authorized administrator of Marquette Law Scholarly Commons. For more information, please contact 


\section{A Review of Federal Sentencing Treatises and Periodicals}

$\mathrm{I}$ $n$ their eleven years of existence, the Federal Sentencing Guidelines have given rise to an everexpanding body of technical case law. Due to their length and complexity, as well as their reliance on novel terms and concepts without clearly articulated purposes, ${ }^{\mathrm{I}}$ the Guidelines seem endlessly capable of generating judicial decisions increasingly suggestive of angels dancing on the heads of pins. Thus, it has recently been observed, there are 869 cases available on-line dealing with the distinction between "minimal" and "minor" participation in an offense. ${ }^{2}$ Little surprise that numerous treatises and periodicals have become available to help practitioners navigate the burgeoning case law. While some critics have characterized these texts as "the most powerful evidence of the tediousness and complexity of the Guidelines regime," ${ }^{3}$ there can be little doubt that they are invaluable resources for those who must live with the guidelines on a day-to-day basis.

This Article describes some of the leading treatises and periodicals in the field. I attempt to focus on distinctions that may be of greatest interest to practitioners. To the best of my knowledge and experience, all of the resources consistently provide accurate and incisive descriptions of leading cases. Accordingly, potential users may be more interested in characteristics such as depth and breadth of coverage, organizational format, physical portability, intended audience, and "extras" like practice aids and legislative history. After discussing the treatises and periodicals individually, I conclude with a brief reflection on what they, collectively, may or may not indicate about the state of federal sentencing law.

\section{Treatises}

The specialized federal sentencing treatises generally provide the complete text of the Guidelines and a discussion of leading cases, grouped by topic area. Most contain appendices that reprint background documents, such as Sentencing Commission reports and the $1_{9} 83$ Senate Judiciary Committee Report on the Sentencing Reform Act, the principal legislative history document relating to the Guidelines. The appendices vary significantly in size according to the number and length of background documents included. The treatises also vary in organization, intended audience, and the coverage of material other than the published case law. ${ }^{4}$ In view of these differences, each treatise seems relatively better adapted for certain uses than others.

\section{A. Federal Sentencing Law and Practice}

For routine use in locating relevant legal authority, practitioners are not likely to find a resource superior to Federal Sentencing Law and Practice, authored by Thomas W. Hutchison, David Yellen, Peter B. Hoffman, and Deborah Young. Issued by West Publishing Company as an annually-updated, softcover volume, FSLQP $P$ is organized along the lines of the guidelines themselves. It provides the complete text of each guideline, including the official commentary, followed by an Authors' Comments section that discusses past amendments and case law. Two final chapters cover departures and appeals of sentences. Throughout the treatise, leading cases, circuit splits, and unresolved legal questions are clearly identified. However, few individual cases receive detailed treatment, with many appearing only within a string citation. For difficult or important issues, as with all the treatises, FSLQIP is by no means a substitute for reading the cases themselves.

Nor does FSLQP venture much beyond the published case law and the guidelines themselves, largely ignoring matters such as sentencing procedure and tactics. The treatise sometimes places its discussion of the law within a policy context, citing relevant law review articles, but, like all of the treatises discussed here, its primary focus remains descriptive, rather than prescriptive or theoretical. The virtues of FSLQP lie in the quantity of cases collected, the user-friendly organization, and the succinct synthesis of large numbers of cases. These characteristics make FSLQP an ideal starting point for finding quick answers to substantive questions of federal sentencing law.

\section{B. Federal Sentencing Guidelines Handbook}

The Federal Sentencing Guidelines Handbook, authored by Roger W. Haines, Jr., Jennifer C. Woll, and Frank O. Bowman, III, offers an analysis of the Guidelines that is strikingly similar in structure and tone to that of FSLQP. Published by West as a single soft-cover volume, the Handbook provides the full text of each guideline followed by an Authors' Discussion section, which covers relevant case law, amendments, and articles. The first chapter includes a brief roadmap of the Guidelines, a survey of constitutional and statutory challenges, and a review of appeals procedures. Commission documents, including a 1997 study of departures, are reprinted in the appendices.

The Handbook's forte, like that of FSLQP, lies in

\section{$\lim _{x \rightarrow \infty}^{x}$ \\ MICHAEL M. O'HEAR}

Michael M. O'Hear is an

associate with

Sonnenschein Nath \&

Rosenthal in Chicago. 
its exhaustive collection and organization of the cases. However, FSLQP tends to provide more synthesis and analysis of the case law - the Handbook reads in parts like a simple catalog of case holdings. On the other hand, FSLQP lacks the Commission materials contained in the Handbook's appendices. Overall, most users will find the two treatises to be far more alike than not.

\section{Practice Under the Federal Sentencing Guidelines} Practice Under the Federal Sentencing Guidelines, edited by Phylis Skloot Bamberger and David J. Gottlieb, possesses a rather different set of strengths and weaknesses. Published by Aspen Law and Business as a three-volume, hard-cover, looseleaf set, this treatise is physically cumbersome and less likely to make its way into briefcases and courtrooms than the first two. Organized in an idiosyncratic fashion, it is not designed to provide quick answers regarding the application of specific guidelines. However, because it is not rigidly organized according to the structure of the guidelines, the treatise may offer a particularly coherent introduction to federal sentencing for students and practitioners new to the field.

Practitioners may also be attracted by the treatise's attention to procedure and strategy, in addition to substantive law, even to the point of reprinting the relevant local court rules of selected jurisdictions. Scholars and policymakers, as well as some practitioners, may be drawn by the treatise's coverage of constitutional and statutory issues, and by its lengthy appendices, which include the $1_{9} 83$ Senate Judiciary Committee Report, Department of Justice memoranda regarding prosecutorial policies, evaluative reports of the guidelines, and Commission documents, such as its review of most frequently asked questions.

PUFSG's first volume consists of sixteen chapters covering the basic elements of guideline sentencing (e.g., offense level and criminal history), issues pertaining to specific offenses (e.g., environmental crimes and insider trading), procedural aspects of sentencing (e.g., pleas and appeals), and constitutional and statutory challenges to the Guidelines. Different authors have prepared each chapter, including distinguished public defenders, academics, and members of the private bar. (A small number of the authors have prosecution backgrounds, but the roster of authors is decidedly tilted towards the defense side, which is reflected to some extent in the treatise's tone.) While the varying authors may bring relatively more practical or academic orientations to their work, the chapters are uniformly thoughtful and accessible. The second and third volumes reprint the various official documents referred to above. In sum, PUFSG is a comprehensive reference work that may be of greatest interest to practitioners relatively new to the field, or who are confronted with sentencing issues that do not fit into the guidelines framework, such as procedural problems or statutory and constitutional issues.

\section{Federal Sentencing Manual}

The authors of the Federal Sentencing Manual, Gerald T. McFadden, Judy C. Clarke, and Jeffrey L. Staniels, come from defense backgrounds, and their stated purpose is to address the needs of defense counsel. To a much greater extent even than PUFSG, the Manual will likely hold limited appeal for those not on the defense side.

Published by Matthew Bender as a two-volume, hard-cover, looseleaf set, the Manual is really a how-to text. It includes sample briefs and other court filings, detailed discussions of sentencing procedures, and such basic, practical information as the names and locations of federal correctional facilities. The first volume contains fifteen chapters, spanning the basic elements of guideline sentencing; the history and purposes of the guidelines; the functioning of the Commission; issues specific to drug and white-collar sentencing; procedures relative to all stages of sentencing; Supreme Court review; and leading cases that favor the defense side. Each chapter discusses relevant legal authorities, but many focus on logistical and tactical advice for defense counsel.

The second volume contains lengthy appendices, which focus on Commission documents and legislative history. In comparison with PUFSG, the Manual's appendices provide more complete coverage of the legislative history of the Sentencing Reform Act, including the House Committee Report, and of the Commission's promulgation of the Guidelines, including the dissent by Commissioner Paul Robinson. The Manual lacks coverage of Department of Justice memoranda and of local rules of court.

Due to its size and organization, the Manual, like PUFSG, may not provide the most convenient method for research of substantive sentencing law. Yet, both treatises excel in providing coverage of procedural topics, copious appendices, and thoughtful analysis. Of the two, the Manual is more uniformly practical, in a detail-oriented sense, as well as more expressly directed to the needs of defense counsel. Thus, if permitted only one treatise for their shelves, many defense lawyers might well choose this one.

\section{E. Guideline Sentencing}

In stark contrast to the cornucopia of materials contained in both the Manual and PUFSG, the Federal Judicial Center publishes an outline that narrowly focuses on appellate sentencing decisions. Authored by Jefri Wood and Diane Sheehey, the soft- 
cover Guideline Sentencing: An Outline of Appellate Case Law on Selected Issues is organized along the lines of the Guidelines Manual (although the Guidelines are not reprinted). For each section of the Guidelines, the authors discuss issues that have been addressed by the appellate courts, identifying circuit splits and guideline amendments made in response to the case law. Two final chapters discuss sentencing procedure and appellate review. Most cases are discussed in summary fashion, with minimal discussion of the facts or the court's reasoning. Thus, the outline adds little to the treatises discussed above. Although the relatively slim volume is portable and easy to use, practitioners may prefer the somewhat more comprehensive coverage available in the other single-volume works, such as district court opinions and the text of the guidelines themselves.

\section{F. Others}

In addition to treatises that exclusively address federal sentencing law and practice, a number of other resources are available. For instance, Arthur W. Campbell's The Law of Sentencing, a single-volume treatise with annual updates, published by Clark Boardman Callaghan, includes a brief overview section on the Guidelines. Practitioners and students of federal sentencing may find of greater value Campbell's longer discussions of such topics as sentencing rationales, sentencing alternatives, constitutional considerations, and sentencing procedures.

\section{Periodicals}

Most federal sentencing periodicals focus on providing summaries of significant new cases in the field. Individual cases tend to receive more detailed treatment than in any of the treatises, although cases are generally not contextualized by reference to similar decisions. The periodicals differ with respect to the scope of their coverage, the depth of their analysis, and the intended audience. ${ }^{5}$

\section{A. Federal Sentencing Guide}

Those wishing to stay abreast of current developments in sentencing case law may find the most comprehensive resource to be the Federal Sentencing Guide, a biweekly newsletter published by James Publishing and authored by Roger W. Haines, Jr., and Jennifer C. Woll. An outgrowth of the former Federal Sentencing \& Forfeiture Guide, which divided its two coverage areas into two new newsletters, the Guide is organized according to Guideline chapters and sections. Every two weeks, the newsletter provides citations and brief descriptions of new cases pertaining to each guideline. The cases receive a few sentences each, generally conveying a thumbnail sketch of the court's reasoning, but providing minimal factual detail, analysis, or comparison with other cases. Although the principal author is an experienced Assistant United States Attorney, neither the coverage nor the analysis of the Guide is noticeably skewed to prosecution interests. In addition to case summaries, the Guide provides updates on Commission activities.

Case descriptions in the Guide are periodically compiled into hardbound volumes, with regular softbound supplements. Subscribers also receive bimonthly indexes of new cases. The shelf space required by the many newsletters, indexes, and compilations included in the set amply demonstrates the present quantity and difficulty of federal sentencing law. While the sheer volume of the cases covered by the Guide is daunting, there may be no better resource for keeping fully abreast of the case law short of reviewing every new sentencing decision as it becomes available on-line.

\section{B. Guideline GrapeVIne "Lite"}

Guideline Grapevine "Lite" similarly provides thumbnail sketches of new cases, but with a particular emphasis on cases of interest to defense counsel. Edited by Judy Clarke and Gerald R. Smith, and published monthly by the Federal Defender of Eastern Washington and Idaho, Guideline Grapevine became Guideline Grapevine "Lite" in I996 when the newsletter discontinued its coverage of cases regarded as routine. The newsletter now summarizes cases that fall into one of four categories: I) defense victories; 2) circuit conflicts; 3) cases with new or refined interpretations of guideline issues; and 4) cases "that make an interesting point." While the coverage and organization of GGL tilts towards cases of interest to the defense side, the analysis of individual cases is not particularly slanted.

GGL organizes cases in an idiosyncratic manner: rather than following the organization of the Guidelines, the newsletter divides the case law into various broad issue areas, which are set forth in alphabetical order. Within each issue area, cases are further subdivided by circuit, permitting readers to focus on jurisdictions of greatest interest to them. Each issue begins with a table of contents and a brief summary of defense highlights among the new cases. While the newsletter's coverage appears less comprehensive than that of the Federal Sentencing Guide, practitioners, at least on the defense side, may appreciate the screening and highlighting that the editors perform.

\section{Guideline Sentencing Update}

Though not published on a regular schedule, the Federal Judicial Center's Guideline Sentencing Update provides readers with periodic updates on case law 
developments. Roughly a dozen issues per year are distributed to judges and judicial personnel; others may access the Update through the Judicial Center's web page (http://www.fjc.com). Issues are four pages in length, and generally cover seven or eight new appellate decisions. The Update covers substantially fewer new cases than either GGL or the Federal Sentencing Guide, but provides more information about the cases that it does report. Still, many users may prefer the more regular and comprehensive coverage offered by other periodicals.

\section{Federal Sentencing Reporter}

The readers of this Article probably require little introduction to FSR. Published 6 times yearly, this journal occupies a unique niche among the periodicals dealing with federal sentencing. FSR provides comparatively little reporting of new cases (although it does reprint a handful of significant decisions each year). Instead, FSR devotes the lion's share of its space to articles contributed by a broad range of practitioners, judges, academics, and policymakers. Most issues focus on a particular topic, such as criminal history, the purposes of sentencing or internal Sentencing Commission procedures. The articles are significantly briefer than standard law review fare, but share with law reviews an analytical and normative bent that is generally absent from other specialized sentencing periodicals. Some articles read like editorials; others offer important new research. The editors helpfully collected fourteen of the most important past articles in the July/August 1997 issue.

FSR also regularly publishes news and notices regarding Commission and Congressional activity; reports and proposals from the Commission, the Federal Judicial Center, and other bodies; and the text of rules and statutes. FSR digests this stew of materials in an "Editor's Observations" section at the beginning of each issue.

There can be little doubt of FSR's unique value to policymakers, academics, and anyone who wishes to participate in, or remain apprised of, the ongoing process of sentencing reform in this country. Readers more narrowly oriented towards the practice of federal sentencing law may occasionally find themselves mystified by FSR's eclectic choice of topics, such as an issue devoted to crime and sentencing in Canada. Nor does FSR provide anything close to thorough coverage of case law developments. FSR nonetheless regularly covers topics that should be of great interest to practitioners, and uniformly does so with thoughtfulness and depth. For instance, an issue devoted to Koon v. United States, which appeared shortly after the Supreme Court's decision was released, provided an impressive range of perspectives on the opinion, thoroughly exploring the interpretive possibilities in a manner beyond the scope of traditional case reporting services.

\section{E. General Criminal Law Periodicals}

Other periodicals devoted to criminal law generally also provide excellent coverage of developments in federal sentencing law. BNA's Criminal Law Reporter, a weekly publication, discusses new sentencing cases in most issues. The newsletter also covers action by the Commission and Congress, significant speeches and symposia, and relevant evaluative studies. The most important cases and other documents, including Supreme Court opinions, are reprinted in full; other cases are merely summarized. These summaries, particularly of highlighted cases, tend to be significantly more complete than those in the Federal Sentencing Guide and GGL, often including lengthy quotations from the court's opinion. Cumulative indexes, organized by topic areas, are available.

The Criminal Practice Report, published biweekly by Pike \& Fischer, similarly touches on sentencing in most issues, but with a bit less emphasis on case law and policy developments. In addition to printing legislative news and case summaries, some of which are quite lengthy, the Report also contains practice aids, such as forms and sample motions, and brief articles providing ideas and advice for practitioners. In sum, the Criminal Practice Report, like the Criminal Law Reporter, may have advantages over some of the more specialized federal sentencing periodicals in that the scope of its coverage extends well beyond traditional case law developments and in that the most important cases are presented with extensive digesting. However, practitioners and students should be aware that only a small minority of sentencing cases find their way into the pages of the more general periodicals.

\section{Conclusion}

Federal sentencing law under the Guidelines has often been compared to tax law - dry, technical, and arcane. ${ }^{6}$ For all their practical virtues - and these I do not mean to sell short - treatises and periodicals in the field tend to reflect the interests of the published judicial decisions upon which they are based, i.e., narrow interpretive questions relating to specific guidelines. Perusing the secondary sources, one is inclined to agree with critics who complain that the Guidelines have transformed the "traditional ritual of sentencing" from an exercise in moral judgment into an obscure mathematical operation.? Professor Kate Stith and Judge Jose A. Cabranes have described the treatises and periodicals discussed above in strong terms:

These compendiums are a monument to the 
effort that federal judges across the nation have devoted to applying the often unexplained, if not arbitrary, rules promulgated by the Sentencing Commission - an effort which, lamentably, is squandered in the obscure. ${ }^{8}$

In the view of Professor Stith and Judge Cabranes, sentencing courts should instead focus on the "moral principles embodied in our laws" and, at sentencing, should "weigh all of the circumstances of the particular case and all of the purposes of criminal punishment." 9

Yet, in viewing federal sentencing practice through the lens of legal treatises, some caution is in order: such texts are largely compendiums of published judicial decisions. Judicial decisions rarely become published if they do not address significant questions of law. And, in point of fact, the vast majority of the cases covered in all of the treatises and periodicals discussed above are appellate decisions. ${ }^{\text {to }}$ The daily work of federal district judges - their exercises of nonreviewable discretion, their demeanor at sentencing, their articulation of the considerations underlying a particular sentence-largely occurs within the proverbial black box as far as the published case law is concerned. Without knowledge of these crucial elements of the sentencing "ritual," any conclusions as to the moral content of the ritual must be guarded.

Indeed, the Guidelines leave a not insignificant number of avenues for district court judges to exercise moral judgment." Some avenues require covert judicial action. As Professor Stith and Judge Cabranes acknowledge, judges can, and do, circumvent guideline results they find unjust through their fact-finding powers. ${ }^{12}$ Other avenues are more open. ${ }^{13}$ Judges are free to choose sentence lengths within prescribed ranges, and, for lower ranges, have substantial discretion as to the type of sentence imposed. Judges may in some cases depart from the guidelines, leaving even greater discretion as to duration and type of sentence, particularly where the government has made a substantial assistance motion. Certain guideline factors are also conducive to discretion and moral judgment, such as the acceptance of responsibility adjustment. ${ }^{14}$

Of course, these exercises of moral judgment are not likely to make their way into treatises and periodicals. In some cases, the judgment is of necessity exercised sub silentio; in others, the district court is exercising its discretion in ways that are more or less contemplated by the Guidelines to be nonreviewable. In any event, what is missing in sentencing is not moral judgment, but, in my view, moral dialogue. When judges wrestle, consciously or not, with the big questions left unanswered by the guidelines - which purposes of sentencing are appropriate for which offenses, which offender characteristics militate for and against lenience and how much, what are the "just deserts" for a given crime-judges generally do so without the benefit of any written reasoning on these issues from other judges in similar cases. As Professor Stith and Judge Cabranes observe, the guidelines regime has been no more successful than the prior fully-discretionary system in fostering the "judicial development of sentencing principles and standards." ${ }^{\text {Is }}$ While there is no shortage of sentencing cases, no genuine common law of sentencing exists. And this, depending on one's view of the federal judiciary's proper role in sentencing, may be the real problem (or achievement) that is highlighted by the content of the sentencing treatises and periodicals.

\section{Notes}

1 These characteristics of the guidelines are well described in Kate Stith \& Jose A. Cabranes, Judging Under the Federal Sentencing Guidelines, 91 Nw. U. L. REv. 1247, 1270.74 (1997).

2 ld. at 1267 n.74.

3 /d. at 1269.

4 Notwithstanding the variations in coverage, none of the treatises include a serviceable guide to sentencing literature and research. Also, while more general sentencing treatises are available, the specialized federai sentencing treatises on which I focus provide only minimal coverage of pre-guidelines sentencing and state sentencing. Their subject matter is truly federal sentencing in the guidelines era.

5 Many law reviews have also published articles on federal sentencing, although these tend to be more theoretical or normative than most of the periodicals discussed here. Of particular note, several law reviews have published symposium issues relating to the Guidelines. These include The Federal Sentencing Guidelines: Ten Years Later, 91 Nw. U. L. REv. 1231 (1997); A Decade of Sentencing Guidelines: Revisiting the Role of the Legislature, 28 WAKE ForEst L. REV. 181 (1993); Corporate Sentencing, 71 WASH. U.L.Q. 189 (1993); Federa/ Sentencing, 66 S. CAL. L. Rev. 99 (1992); Punishment, 101 YaLe L.J. 1681 (1992); Federal Sentencing Guidelines, 29 Am. CRIM. L. Rev. 823 (1992); Making Sense of the Federal Sentencing Guidelines, 25 U.C. Davis L. Rey. 571 (1992); The Sentencing Controversy: Punishment and Policy in the War Against Drugs, 40 VILL. L. REv. 301 (1992); Reconsidering Rehabilitation, 65 Tulane L. Rev. 1011 (1991); and Sentencing, 27 Aм. Crim. L. Rev. 331 (1989).

6 See, e.g., Roger W. Haines, Jr., et al., Federal Sentencing GUIDELINES HANDBOOK 12 (1997) (observing that Guidelines are "mindnumbingly detailed" like the tax code).

7 Stith \& Cabranes, supra note 1, at 1252.53.

8 ld. at 1269.

9 Id. at 1252.

${ }^{10}$ Even more narrowly, the secondary sources exclude the "unpublished" memorandum opinions of the appellate courts, which are generally available on-line but cannot be cited as authority in other cases.

11 By this term, I mean the discretionary balancing of the circumstances of the case and the purposes of criminal punishment. See id. at 1252 .

12 ld. at 1265 .

${ }^{13}$ Some of these are discussed in Thomas N. Whiteside, The Reality of Federal Sentencing: Beyond the Criticism, 91 Nw. U. L. Rev. $1574,1590-97$ (1997).

14 Paul H. Robinson, The Federa/ Sentencing Guidelines: Ten Years 
Later-An Introduction and Comments, 91 Nw. U. L. Rev, 1231, 1233-34(1997).

15 Stith \& Cabranes, supra note 1 , at $1270-71$. While sentencing standards may now exist in a sense that they did not before 1984 , these standards are bureaucratic, not judicial, in origin, and lack articulated principles and a grounding in the realities facing district court judges. For instance, the acceptance of responsibility guideline sets forth a standard (deduct two points if the defendant demonstrates acceptance), but fails to articulate any principle to be served. This leaves important ambiguities for each sentencing judge to work out on his or her own, notably the extent to which a guilty plea alone suffices to earn the deduction. See generally Michael M. O'Hear, Remorse, Cooperation, and 'Acceptance of Responsibility,' 91 Nw, U. L. REv. 1507 (1997). 